\title{
Hematological and biochemical profiles of rats submitted to experimental poisoning with Tityus serrulatus venom
}

[Perfis hematológicos de ratos submetidos ao envenenamento escorpiônico experimental por Tityus serrulatus]

\author{
M.C.L. Pinto, M.M. Melo*, M.E.R. Costa, C.R. Labarrere \\ Escola de Veterinária - UFMG \\ Caixa Postal 567 \\ 30123-970 - Belo Horizonte, MG
}

\begin{abstract}
The hematological and biochemical profiles of newly weaned rats submitted to experimental poisoning with $T$. serrulatus venom were evaluated. Fifteen recently weaned male Wistar rats (mean weight $130 \mathrm{~g}$ ) were distributed into three equal groups $(n=5$ ). Animals in the control group (group A) received a subcutaneous injection of $400 \mu \mathrm{L}$ of ultra-pure water, while those in the experimental groups received, by identical route, $400 \mu \mathrm{L}$ of a solution containing $100 \mu \mathrm{g}$ (group B) or $450 \mu \mathrm{g}$ (group C) of scorpion venom dissolved in ultra-pure water. Red blood cells indexes, and differential leukocyte and total platelet counts were determined, together with levels of serum glucose, urea, creatinine, lactic dehydrogenase, aspartate aminotransferase, amylase, insulin, and cortisol. No significant differences between the control and experimental groups regarding red blood cells indexes were found. In contrast, significant increases $(\mathrm{P}<0.05)$ in neutrophils, lymphocytes, and monocytes were observed in animals from groups B and C compared with the control group, while the number of platelets decreased. Serum glucose concentration remained unchanged in all groups, but important alterations were observed in the values of urea and creatinine. The results show that scorpion venom was detrimental to renal function as demonstrated by the altered urea and creatinine levels. Pancreatic function was also impaired, as revealed by the increase in amylase activity and the reduction in insulin levels.
\end{abstract}

Keywords: rat, Tityus serrulatus, scorpion, experimental envenoming, hematology, biochemestry

\section{RESUMO}

Avaliaram-se os perfis hematológico e bioquímico de ratos recém-desmamados submetidos ao envenenamento experimental com veneno de Tityus serrulatus. Quinze ratos Wistar machos, média de peso de $130 \mathrm{~g}$, foram distribuídos aleatoriamente em três grupos $(n=5)$. Os animais do grupo-controle A foram inoculados com $400 \mu \mathrm{L}$ de água ultrapura, os do grupo experimental B receberam $400 \mu \mathrm{L}$ de uma solução contendo $100 \mu \mathrm{g}$ de veneno e os do grupo experimental C receberam $400 \mu \mathrm{L}$ de uma solução contendo $450 \mu \mathrm{g}$ de veneno. Foram determinados os índices da série vermelha, a contagem total e diferencial dos leucócitos e a contagem total de plaquetas, bem como os níveis da desidrogenase lática, aspartato aminotransferase, amilase, glicose, ureia, creatinina, cortisol e insulina. Não houve diferenças significativas entre o grupo-controle e os experimentais com relação aos índices da série vermelha. Foram observados aumentos significativos $(P<0,05)$ no número de neutrófilos, linfócitos e monócitos nos ratos dos grupos $B$ e $C$, enquanto o número de plaquetas diminuiu. A concentração de glicose permaneceu inalterada em todos os grupos, mas foram observadas importantes alterações nos valores séricos de ureia e creatinina. Esses resultados mostraram que o veneno de escorpião comprometeu o funcionamento dos rins. Como demonstrado pelo aumento da atividade da amilase sérica e a redução dos níveis de insulina, a função pancreática também foi afetada.

Palavras-chave: Tityus serrulatus, escorpiões, envenenamento experimental, parâmetros hematológicos e bioquímicos

Recebido em 28 de maio de 2009

Aceito em 31 de março de 2010

* Autor para correspondência (corresponding author)

E-mail: marilia@vet.ufmg.br 


\section{INTRODUCTION}

The high incidence of envenomation by scorpions is a matter of considerable concern in many Asian, African, and American countries, and especially in Brazil. The severe clinical manifestations of scorpion poisoning are generally associated with alterations in haemodynamics and the cardio-respiratory system (Cupo and Hering, 2002). Indeed, cardiovascular problems induced by scorpion venom may result in serious consequences and often death, mainly amongst young patients. In humans, cholinergic discharge may cause pancreatitis leading to augmented exocrine function as exemplified by an increase in serum amylase levels. Renal alterations have also been described in patients presenting severe conditions.

Scorpion venom comprises a complex mixture of toxins including short and long chain peptides, mucopolysaccharides, lipids, hyaluronidases, and bioactive amines (Couraud and Jover, 1984; Gazarian et al., 2005). The main constituents of the venom are the neurotoxins, which act on the ion channels of the neuronal membranes releasing massive amounts of neurotransmitters. Such autonomic discharges can produce adrenergic and cholinergic effects of variable intensity (Possani et al., 1999; Castro et al., 2000; Vasconcelos et al., 2005).

Tityus serrulatus is the most prevalent species of scorpion in Brazil and is responsible for the majority of incidents involving accidental envenomation. The aim of the present study was to characterise the hematological and biochemical profiles of newly weaned rats that had been submitted to experimental poisoning with $T$. serrulatus venom. It was anticipated that the results might have applications in the development of animal medication and also in the field of human therapy.

\section{MATERIAL AND METHODS}

The research project was approved by the Ethical Committee for Animal Experimentation at the Universidade Federal de Minas Gerais, on $14^{\text {th }}$ March 2008, under protocol number 171/2008.

Venom was extracted from specimens of $T$. serrulatus that had kindly been provided by the
Centro de Controle de Zoonose at Ituiutaba, MG. Fifteen recently weaned male Wistar rats with a mean weight of $130 \mathrm{~g}$ (range $110-150 \mathrm{~g}$ ) were supplied by the biotery at the Instituto de Ciências Biológicas, UFMG. Animals were housed in cages $(40 \times 45 \times 45 \mathrm{~cm})$ maintained under appropriate conditions, and received commercial chow (Labina, Purina - Paulínia, Brazil) and water ad libitum.

Animals were distributed into three equal groups $(\mathrm{n}=5)$. Those in the control group A received $400 \mu \mathrm{L}$ of ultra-pure water (placebo) administered via subcutaneous injection into the interscapular region using a disposable $1 \mathrm{~mL}$ hypodermic syringe. Each of the rats in the experimental groups received, by identical route, $400 \mu \mathrm{L}$ of a solution containing $100 \mu \mathrm{g}$, group B, or $450 \mu \mathrm{g}$, group $\mathrm{C}$, of scorpion venom dissolved in ultra-pure water. The respective applied doses were equivalent to 0.33 and 1.5 times the $\mathrm{LD}_{50}$ value of the venom for rats. Forty minutes after the administration of placebo or venom, animals were anaesthetised by intramuscular injection of a mixture of xylazine hydrochloride $(10 \mathrm{mg} / \mathrm{kg})$ and ketamine $(75 \mathrm{mg} / \mathrm{kg})$, and blood was collected by intracardiac puncture. Blood samples were stored in tubes in the absence or presence of anticoagulant (10\% ethylenediaminetetraacetic acid).

The concentration of hemoglobin was determined in total blood, and erythrocyte and leukocyte counts were performed using an electronic counter (Model CC-530, CELM Barueri, Brazil). Blood smears were prepared on glass slides (26 x 79mm), fixed with MayGrunwald solution and stained with Giemsa in order to carry out differential counting of leukocytes and total number of platelets (Ferreira Neto et al., 1982). The hematocrit (HCT) was determined using a microhematocrit centrifuge (Model Spin 1000, Micro Spin - USA).

Lactic dehydrogenase (LDH), aspartate aminotransferase (AST), amylase, urea, creatinina, and glucose levels were determined in serum samples using commercial kits (Bioclin Belo Horizonte, MG, Brazil; Synermed - Burgess Hill, UK) and a Cobas Mira Classic chemical analyzer (Roche - Indianapolis, USA). The concentrations of cortisol and insulin were determined using commercial radioimmunoassay kits (Coat-A Count, Diag. Prod. Corp. - Los 
Angeles) and a Cobra II Auto-Gamma counter (Packard Instrument Co. - Meriden, USA).

The experiment followed a completely random design. Data were subjected to Lillifors, Kolmogorov-Smirnov and Shapiro-Wilk normality tests. Variables presenting a nonparametric distribution were analyzed using Kruskal-Wallis test, whilst analysis of variance was applied to variables that were normally distributed; and mean values of which were compared using the Student Newman Keuls (SNK) test. Statistical analyses were carried out by SAS software and SAEG (Sistema..., 2007).

\section{RESULTS AND DISCUSSION}

No significant differences were observed among the control and experimental groups regarding red blood cells indexes (Table 1). It is possible that an interval of $40 \mathrm{~min}$ between the administration of venom and the collection of blood was insufficient for changes in the erythrogram to be detectable. Some studies, in which longer intervals were applied between envenomation and sampling, have revealed increases in hemoglobin concentration and in HCT following experimental poisoning by $T$. serrulatus (Bertazzi et al., 2003; Ribeiro et al., 2009).

The leukogram displayed in Table 2 shows that the total numbers of leukocytes in animals of the experimental groups were significantly $(\mathrm{P}<0.05)$ higher than in the control group, with the maximum value being observed in rats that had received the highest dose of venom (group C). Neutrophilic leukocytosis has been previously reported in humans (Gueron and Ovsyshcher, 1987; Gueron et al., 1993; Bucaretchi et al., 1995) and animals (Cordeiro et al., 2006; Ribeiro et al., 2009) envenomated by scorpions, and results from the stress caused by pain and from the recruitment of neutrophils from the marginal to the circulating blood compartments. In this context, there were significant $(\mathrm{P}<0.05)$ increases in the number of ring cells (heterologous neutrophils that are normally found in rodents) in the experimental groups compared with the control, but no alterations were observed with respect to band neutrophils.

Table 1. Red blood cells indexes determined in rats submitted to experimental poisoning with Tityus serrulatus venom

\begin{tabular}{ccccccc}
\hline Group & $\begin{array}{c}\text { Erythrocytes } \\
(\mathrm{x} \mathrm{10} / \mu \mathrm{L})\end{array}$ & $\begin{array}{c}\text { Hemoglobin } \\
(\mathrm{g} / \mathrm{dL})\end{array}$ & $\begin{array}{c}\text { Hematocrit } \\
(\%)\end{array}$ & $\begin{array}{c}\text { Mean corpuscular } \\
\text { volume }(\mathrm{fL})\end{array}$ & $\begin{array}{c}\text { Mean } \\
\text { corpuscular } \\
\text { hemoglobin }(\mathrm{pg})\end{array}$ & $\begin{array}{c}\text { Mean } \\
\text { corpuscular } \\
\text { hemoglobin } \\
\text { concentration } \\
(\%)\end{array}$ \\
\hline A & $6.62 \pm 0.66$ & $13.3 \pm 0.55$ & $43 \pm 1.0$ & $65.32 \pm 7.3$ & $20.1 \pm 2.3$ & $30.9 \pm 1.6$ \\
B & $6.69 \pm 1.32$ & $13.5 \pm 1.54$ & $41 \pm 6.1$ & $61.42 \pm 4.5$ & $20.4 \pm 1.9$ & $33.1 \pm 1.1$ \\
C & $7.09 \pm 0.45$ & $13.8 \pm 0.72$ & $45 \pm 2.5$ & $63.24 \pm 4.5$ & $19.4 \pm 1.3$ & $30.8 \pm 0.7$ \\
\hline
\end{tabular}

There were no statistical differences between the mean values according to ANOVA and SNK test $(\mathrm{P}>0.05)$.

Control group A rats received $400 \mu \mathrm{L}$ of ultra-pure water as placebo; experimental group B rats received $400 \mu \mathrm{L}$ of a solution containing $100 \mu \mathrm{g}$ of scorpion venom (a dose equivalent to $1 / 3$ time the $\mathrm{LD}_{50}$ of the venom for rats); experimental group $\mathrm{C}$ rats received $400 \mu \mathrm{L}$ of a solution containing $450 \mu \mathrm{g}$ of scorpion venom (a dose equivalent to $1 \frac{1}{2}$ time the $\mathrm{LD}_{50}$ of the venom for rats).

Table 2. Differential leukocyte and platelet counts in rats submitted to experimental poisoning with Tityus serrulatus venom

\begin{tabular}{|c|c|c|c|c|c|c|c|c|}
\hline Group & $\begin{array}{c}\text { Total } \\
\text { leukocytes } \\
\left(\mathrm{x} 10^{3} / \mu \mathrm{L}\right)\end{array}$ & $\begin{array}{c}\text { Neutrophils } \\
\left(\times 10^{3} / \mu \mathrm{L}\right)\end{array}$ & $\begin{array}{l}\text { Ring cells } \\
\left(\times 10^{3} / \mu \mathrm{L}\right)\end{array}$ & $\begin{array}{c}\text { Lymphocytes } \\
\left.\text { (x } 10^{3} / \mu \mathrm{L}\right)\end{array}$ & $\begin{array}{c}\text { Band } \\
\text { neutrophils } \\
\left(\times 10^{3} / \mu \mathrm{L}\right)\end{array}$ & $\begin{array}{l}\text { Eosinophils } \\
\left(\mathrm{x} 10^{3} / \mu \mathrm{L}\right)\end{array}$ & $\begin{array}{l}\text { Monocytes } \\
\left(\mathrm{x} 10^{3} / \mu \mathrm{L}\right)\end{array}$ & $\begin{array}{l}\text { Platelets } \\
\left(\mathrm{x} 10^{3} / \mu \mathrm{L}\right)\end{array}$ \\
\hline A & $6.6 \pm 1.1 \mathrm{~b}$ & & 0.090 & & $0.15 \pm 0.8 \mathrm{a}$ & 0.8 & 0. & $73 a$ \\
\hline B & $15.7 \pm 7.1 \mathrm{a}$ & $2.46 \pm 1.3 \mathrm{ab}$ & $0.89 \pm 0.2 \mathrm{a}$ & $11.03 \pm 5.2 \mathrm{ab}$ & $0.35 \pm 0.2 \mathrm{a}$ & $0.2 \pm 0.8 \mathrm{a}$ & $1.42 \pm 0.7 \mathrm{a}$ & $433.0 \pm 93 b$ \\
\hline $\mathrm{C}$ & $29.6 \pm 10.7 \mathrm{a}$ & $5.32 \pm 3.5 \mathrm{a}$ & $0.62 \pm 0.2 \mathrm{a}$ & $19.80 \pm 8.1 \mathrm{a}$ & $0.72 \pm 0.5 \mathrm{a}$ & $0.3 \pm 0.2 \mathrm{a}$ & $0.92 \pm 0.6 \mathrm{a}$ & $381.6 \pm 73 b$ \\
\hline
\end{tabular}

Mean values followed by distinct letters are different according to ANOVA and SNK test $(\mathrm{P}<0.05)$.

Control group A rats received $400 \mu \mathrm{L}$ of ultra-pure water as placebo; experimental group B rats received $400 \mu \mathrm{L}$ of a solution containing $100 \mu \mathrm{g}$ of scorpion venom (a dose equivalent to $1 / 3$ time the $\mathrm{LD}_{50}$ of the venom for rats); experimental group $\mathrm{C}$ rats received $400 \mu \mathrm{L}$ of a solution containing $450 \mu \mathrm{g}$ of scorpion venom (a dose equivalent to $1 \frac{1}{2}$ time the $\mathrm{LD}_{50}$ of the venom for rats). 
The numbers of lymphocytes in animals of groups $\mathrm{B}$ and $\mathrm{C}$ were significantly increased $(\mathrm{P}<0.05)$ in comparison with the control, although the proportion in relation to the total number of leukocytes remained the same (70\%). Since lymphocytes are the most abundant of the white series cells in healthy rats (Thrall, 2004), lymphocytosis may be considered physiological and have contributed to the observed leukocytosis. No differences were detected between the study groups with respect to the number of eosinophils, whereas basophilic granulocytes were not observed in blood smears of the groups.

Although monocytes are normally associated with chronic inflammatory processes, significant $(\mathrm{P}<0.05)$ increases in the number of these cells in experimental animals, compared with controls, were observed 40min after envenomation. Petricevich and Peña (2002) described an immunomodulatory action of macrophages in the early stages of envenoming, as revealed by an increase in the concentration of INF- $\gamma$ (a cytokine responsible for the activation of phagocytosis in macrophages). In a more recent study, Petricevich et al. (2007) demonstrated that the modulation response of macrophages against scorpion venom (and especially against toxin Ts1) includes the release of pre-inflammatory cytokine mediators during the acute phase of envenoming, followed by anti-inflammatory suppressor cytokines, including IL-10, during the later stages.

In the present study, the numbers of platelets in animals of the experimental groups were lower $(\mathrm{P}<0.05)$ than in control group, with the lowest value being observed in rats of group $\mathrm{C}$. Such alterations can be explained by the occurrence of the pulmonary hemorrhages that was macroand microscopically observed. The occurrence of thrombocytopenia is supported by a report (Longenecker and Longenecker, 1981) describing platelet aggregation and disseminated intravascular coagulation resulting from the stimulation of platelet-activating factor in dogs that had been experimentally poisoned with Centruroides sculpturatus venom. Moreover, Corrêa et al. (1997) described hemorrhagic lesions in the heart, lungs, and kidneys of rats submitted to experimental poisoning with $T$. serrulatus venom.

The concentration of glucose remained unchanged in all animals (Table 3). However, important alterations were observed in serum urea and creatinine levels, the values of which indicated that envenomation caused acute renal failure resulting, likely, from the direct effect of the venom and from circulation insufficiency. Whilst the mean values of these parameters were significantly $(\mathrm{P}<0.05)$ enhanced in group $\mathrm{B}$ compared with group $\mathrm{A}$, the increases observed in group $\mathrm{C}$ were not significant with respect to the control since rat 5 from group $\mathrm{C}$ presented a much lower serum urea level than other members of the group, and low individual concentrations of creatinine were exhibited by rats 4 and 5 from group C (Table 4).

The finding that scorpion venom was detrimental to renal function corroborates to previous studies in rats that have shown venom spreads rapidly from blood to tissues, especially kidneys, reaching a maximum concentration at around $15 \mathrm{~min}$ after inoculation (Ismail and AbdElsalam, 1988; Santana et al., 1996; Nunan et al., 2003; 2004). Furthermore, the occurrence of acute renal failure (ARF), with increased urea and uric acid concentration, diminished urinary volume, and tubular congestion, was reported in young patients that had been stung by $T$. serrulatus (Bertazzi et al., 2003). It is known that envenomation by snakes, especially those of the genera Bothrops, can cause ARF not only by direct nephrotoxic activity but also by indirect hypotensive action. Rattle snake venom exhibits strong myotoxic activity which causes ARF as a result of intense myoglobinuria, which is highly detrimental to the kidneys (Varanda and Gianini, 1994). Additionally, it has been shown that rats inoculated with $T$. serrulatus venom exhibit congestion and renal haemorrhage, augmentation of perfusion pressure, reduction in glomerular filtration rate and urinary flow, deposition of protein in the renal tubes, and renal oedema caused by increased hydrostatic pressure (Corrêa et al., 1997; Alves et al., 2005). 
Table 3. Biochemical parameters of serum components in rats submitted to experimental poisoning with Tityus serrulatus venom

\begin{tabular}{|c|c|c|c|c|c|c|c|c|}
\hline Group & $\begin{array}{l}\text { Glucose } \\
\text { (mg/dL) }\end{array}$ & $\begin{array}{c}\text { Urea } \\
(\mathrm{mg} / \mathrm{dL})\end{array}$ & $\begin{array}{l}\text { Creatinine } \\
(\mathrm{mg} / \mathrm{dL})\end{array}$ & $\begin{array}{l}\text { LDH } \\
\text { (U/L) }\end{array}$ & $\begin{array}{l}\text { AST } \\
\text { (U/L) }\end{array}$ & $\begin{array}{c}\text { Amylase } \\
(\mathrm{U} / \mathrm{L})\end{array}$ & $\begin{array}{l}\text { Insulin } \\
(\mu \mathrm{U} / \mathrm{mL})\end{array}$ & $\begin{array}{l}\text { Cortisol } \\
\text { (ng/dL) }\end{array}$ \\
\hline $\mathrm{A}$ & $126 \pm 32 a$ & $35 \pm 8 b$ & $0.6 \pm 0.2 b$ & $805 \pm 128 a$ & $69.2 \pm 42 a$ & $861 \pm 82 a$ & $76 \pm 9 a$ & $94 \pm 2 a$ \\
\hline B & $128 \pm 18 \mathrm{a}$ & $76 \pm 27 a$ & $2.06 \pm 1.2 \mathrm{a}$ & $1423 \pm 1408 a$ & $92.8 \pm 70 \mathrm{a}$ & $1306 \pm 767 a$ & $39 \pm 17 b$ & $92 \pm 4 a$ \\
\hline
\end{tabular}

Mean values followed by distinct letters are different according to ANOVA and SNK test $(\mathrm{P}<0.05)$.

Control group A rats received $400 \mu \mathrm{L}$ of ultra-pure water as placebo; experimental group B rats received $400 \mu \mathrm{L}$ of a solution containing $100 \mu \mathrm{g}$ of scorpion venom (a dose equivalent to $1 / 3$ time the $\mathrm{LD}_{50}$ of the venom for rats); experimental group $\mathrm{C}$ rats received $400 \mu \mathrm{L}$ of a solution containing $450 \mu \mathrm{g}$ of scorpion venom (a dose equivalent to $1 \frac{1}{2}$ time the $\mathrm{LD}_{50}$ of the venom for rats).

Table 4. Levels of serum urea and creatine in individual rats submitted to experimental poisoning with Tityus serrulatus venom

\begin{tabular}{cccc}
\hline Group & Rat No. & Urea $(\mathrm{mg} / \mathrm{dL})$ & Creatinine $(\mathrm{mg} / \mathrm{dL})$ \\
\hline \multirow{3}{*}{ A } & 1 & 49 & 0.8 \\
& 2 & 33 & 0.6 \\
& 3 & 29 & 0.6 \\
& 4 & 28 & 0.6 \\
& 5 & 34 & 0.6 \\
\hline \multirow{2}{*}{ B } & 1 & 104 & 2.1 \\
& 2 & 101 & 0.8 \\
& 3 & 44 & 0.8 \\
& 4 & 75 & 3.3 \\
& 5 & 54 & 3.3 \\
\hline & 1 & 94 & 1.6 \\
& 2 & 60 & 1.3 \\
& 3 & 34 & 1.1 \\
& 4 & 73 & 0.8 \\
& 5 & 49 & 0.8 \\
\hline
\end{tabular}

Control group A rats received $400 \mu \mathrm{L}$ of ultra-pure water as placebo; experimental group B rats received $400 \mu \mathrm{L}$ of a solution containing $100 \mu \mathrm{g}$ of scorpion venom (a dose equivalent to $1 / 3$ time the $\mathrm{LD}_{50}$ of the venom for rats); experimental group $\mathrm{C}$ rats received $400 \mu \mathrm{L}$ of a solution containing $450 \mu \mathrm{g}$ of scorpion venom (a dose equivalent to $1 \frac{1}{2}$ time the $\mathrm{LD}_{50}$ of the venom for rats).

In comparison with the control group, serum $\mathrm{LDH}, \mathrm{AST}$, and amylase activities increased in animals of groups B and C (Table 3), although the differences between groups were not significant $(\mathrm{P}>0.05)$. The observed increases in serum amylase activities in the experimental groups indicated the presence of pancreatic lesions, especially in the islets of Langerhans. Pancreas degeneration was confirmed by the significant $(\mathrm{P}<0.05)$ reduction in insulin synthesis (Table 3 ). It has been shown that the secretion of insulin and glucagon may also be influenced by catecholamine discharge induced by the venom resulting in inhibition of the former and stimulation of the latter (El-Asmar, 1984; Ismail and Abd-Elsalam, 1988; Murthy and Hase, 1994; Murthy and Haghnazari, 1999; Yugandhar et al., 1999). The concentration of cortisol in the serum remained unchanged in animals of all groups (Table 3 ).

\section{CONCLUSIONS}

Envenomation by $T$. serrulatus caused relative polycythemia, leukocytosis with lymphocytosis, and a diminution in the number of platelets in 
recently weaned rats. The venom was detrimental to renal function as demonstrated by increased serum urea and creatinine levels. Pancreatic function was also impaired as demonstrated by the increase in amylase activity and the reduction in insulin levels.

\section{ACKNOWLEDGMENTS}

The authors wish to thank the Fundação de Amparo a Pesquisa do Estado de Minas Gerais (FAPEMIG) and the Conselho Nacional de Desenvolvimento Científico e Tecnológico (CNPq) for financial support for this project. Pinto M.C.L. would like to thank Coordenação de Aperfeiçoamento de Pessoal de Nível Superior (CAPES) for a scholarship.

\section{REFERENCES}

ALVES, R.S.; NASCIMENTO, N.R.F.; BARBOSA, P.S.F. et al. Renal effects and vascular reactivity induced by Tityus serrulatus venom. Toxicon, v.46, p.271-276, 2005.

BERTAZZI, D.T.; ASSIS-PANDOCHI, A.I.; SEIXAS, A.E.C. et al. Effects of Tityus serrulatus scorpion venom and its major toxin, TsTX-I, on the complement system in vivo. Toxicon, v.41, p.501-508, 2003.

BUCARETCHI, F.; BARACAT, C.E.; NOGUEIRA, R.J.N. A comparative study of severe scorpion envenomation in children caused by Tityus bahiensis and Tityus serrulatus. Rev. Inst. Med. Trop. São Paulo, v.37, p.331-336, 1995.

CASTRO, M.S.; LARGURA, S.W.R; FONTES, W. et al. Purification and partial characterization of a $6.6 \mathrm{kDa}$ neurotoxin from Tityus fasciolatus venom. In: WORLD CONGRESS OF THE INTERNATIONAL SOCIETY ON TOXINOLOGY, 13., 2000, Paris. Proceedings... Paris, 2000. p.273.

CORDEIRO, F.F.; SAKATE, M.; FERNANDES V. et al. Clinical and cardiovascular alterations produced by scorpion envenomation in dogs. $J$. Venom. Anim. Toxins incl. Trop. Dis., v.12, p.1943, 2006.
CORRÊA, M.M.; SAMPAIO, S.V.; LOPES, R.A. et al. Biochemical and histopathological alterations induced in rats by Tityus serrulatus scorpion venom and its major neurotoxin tityustoxin-I. Toxicon, v.35, p.1053-1067, 1997.

COURAUD, F.; JOVER, E. Mechanism of action of scorpion toxins. In: TU, A.T. (Ed). Handbook of natural toxins, insects, poisons, allergens and other invertebrate venoms. New York: Marcel Dekker, 1984. v.2, p.659-678.

CUPO, P.; HERING, S.E. Cardiac troponin I release after severe scorpion envenoming by Tityus serrulatus. Toxicon, v.40, p.823-830, 2002.

EL-ASMAR, M.F. Metabolic effect of scorpion venom. In: TU, A.T. (Ed). Handbook of natural toxins, insects, poisons, allergens and other invertebrate venoms. New York: Marcel Dekker, 1984. v.2, p.551-575.

FERREIRA NETO, J.M.; VIANA, E.; MAGALHÃES, L.M. Patologia clínica veterinária. 2.ed. Belo Horizonte: Rabelo, 1982. $279 \mathrm{p}$.

GAZARIAN, K.G.; GAZARIAN, T.; HERNÁNDEZ, R. et al. Immunology of scorpion toxins and perspectives for generation of anti-venom vaccines. Vaccine, v.23, p.33573368, 2005.

GUERON, M.; OVSYSHCHER, I. What is the treatment for the cardiovascular manifestations of scorpion envenomation? Toxicon, v.25, p.121124, 1987.

GUERON, M.; MARGULIS, G.; ILIA, R. et al. The management of scorpion envenomation. Toxicon, v.31, p.1071-1083, 1993.

ISMAIL, M.; ABD-ELSALAM, M.A. Are the toxicological effects of scorpion envenomation related to tissue venom concentration? Toxicon, v.26, p.233-256, 1988 .

LONGENECKER, G.L.; LONGENECKER, H.E. Centruroides sculpturatus venom and platelet reactivity: possible role in scorpion venom induced defibrination syndrome. Toxicon, v.19, p.153-157, 1981.

MURTHY, K.R.K.; HASE, N.K. Scorpion envenoming and the role of insulin. Toxicon, v.32, p.1041-1044, 1994. 
MURTHY, K.R.K.; HAGHNAZARI, L. The blood levels of glucagon, cortisol and insulin following the injection of venom by the scorpion (Mesobuthus tamulus concanesis, POCOCK) in dogs. J. Venom. Anim. Toxins, v.5, p.47-55, 1999.

NUNAN, E.A.; MORAES, M.F.D.; CARDOSO, V.N. et al. Effect of age on body distribution of tityustoxin from Tityus serrulatus scorpion venom in rats. Life Sci., v.73, p.319-325, 2003.

NUNAN, E.A.; ARYA, V.; HOCHHAUS, G. et al. Age effects on the pharmacokinetics of tityustoxin from Tityus serrulatus scorpion venom in rats. Braz. J. Med. Biol. Res., v.37, p.385-390, 2004.

PETRICEVICH, V.L.; PEÑA, C.F. The dynamics of cytokines and nitric oxide secretion in mice injected with Tityus serrulatus scorpion venom. Mediators Inflamm., v.11, p.173-180, 2002.

PETRICEVICH, V.L.; CRUZ, A.H.; CORONAS, F.I.V. et al. Toxin gamma from Tityus serrulatus scorpion venom plays an essential role in immunomodulation of macrophages. Toxicon, v.50, p.666-675, 2007.

POSSANI, L.D.; BECERRIL, B.; DELEPIERRE, M. et al. Scorpion toxins specific for $\mathrm{Na}^{+}$-channels. Eur. J. Biochem., v.264, p.287300, 1999.
RIBEIRO, E.L.; MELO, M.M.; PINTO, M.C.L. et al. Hemograma de cães submetidos ao envenenamento experimental por Tityus serrulatus. Arq. Bras. Med. Vet. Zootec., v.61, p.135-143, 2009.

SANTANA, G.C.; FREIRE, A.C.T.; FERREIRA, A.P.L. et al. Pharmacokinetics of Tityus serrulatus scorpion venom determined by enzyme-linked immunosorbent assay in the rat. Toxicon, v.34, p.1063-1066, 1996.

SISTEMA para análises estatisticas. Versão 9.1. Viçosa: UFV, 2007.

THRALL, M.A. Veterinary hematology and clinical chemistry. Philadelphia: Lippincott Williams \& Wilkins, 2004. 561p.

VARANDA, E.A.; GIANINI, M.J.S.M. Bioquímica de veneno de serpentes. In: BARRAVIERA, B. (Ed). Venenos animais: uma visão integrada. Rio de Janeiro: Científica, 1994. p. $205-223$

VASCONCELOS, F.; LANCHOTE, V.L.; BENDHACK, L.M. et al. Effects of voltage gated $\mathrm{Na}^{+}$channel toxins from Tityus serrulatus venom on rat arterial blood pressure and plasma catecholamines. Comp. Biochem. Physiol. C, v.141, p.85-92, 2005.

YUGANDHAR, B.; MURTHY, K.R.K.; SATTAR, S.A. Insulin administration in severe scorpion envenoming. J. Venom. Anim. Toxins, v.5, p.200-219, 1999. 